


\title{
Small Ruminant Brucella Sero-prevalence and po- tential risk factor at Dallo-Manna and Haranna- Bulluk Districts of Bale Zone, Oromia regional state, Ethiopia
}

\author{
Aliyi Adem ${ }^{1,2 *}$, Adem Hiko ${ }^{2}$, Hika Waktole ${ }^{3}$,Fufa Abunna ${ }^{3}$, Gobena Ameni ${ }^{4}$, Gezahegne \\ $\mathrm{Mamo}^{3}$ \\ ${ }^{1}$ Haranna-Bulluk Pastoral District Office of Bale Zone, Oromia region, Ethiopia. \\ ${ }^{2}$ Haramaya University, College of Veterinary Medicine, P.O. Box 138, Dire Dawa, Ethiopia. \\ ${ }^{3}$ College of Veterinary Medicine and Agriculture, Addis Ababa University, P.O. Box 34, \\ Bishoftu, Ethiopia. \\ ${ }^{4}$ Aklilu Lemma Institute of Pathobiology, Addis Ababa University, P.O.Box 1176, Addis Ababa, \\ Ethiopia. \\ "Corresponding Author: Dr. Aliyi Adem; E-mail: aliyiademgelchu@gmail.com
}

\begin{abstract}
A cross-sectional study was carried out on randomly sampled 384 animals to assess the occurrence of small ruminant brucellosis and risk factors contributing for the zoonotic potential of the disease at Dallo-Manna and HarannaBulluk districts of Bale Zone. Rose Bengal plate test (RBPT) and complement fixation test (CFT) were used serially. All collected serum samples were subjected to RBPT first and then positive sera with RBPT were further tested for confirmation using CFT. Animal level prevalence of $6.5 \%$ and $2.9 \%$, and flock level prevalence of $50 \%$ and $22 \%$ were recorded by RBPT and CFT respectively. Flock level prevalence at Dallo-Manna is 3.8 -fold (95\% OR CI $=1.17-12.19)$ than at Haranna-Bulluk (95\% OR CI $=0.32-3.31)$ but no statistical significant difference $(\mathrm{p}>0.05)$. The Chi-square $\left(\mathrm{x}^{2}\right)$ statistical analysis indicated that age $\left(x^{2}=6.18 ; p<0.05\right)$, parity $\left(x^{2}=0.57 ; p<0.05\right)$, retained fetal membrane $\left(x^{2}=35.5\right.$; $\mathrm{p}<0.001)$ and abortion history $(\mathrm{x} 2=45.1 ; \mathrm{p}<0.001)$ were associated with $\mathrm{Bru}$ cella sero-reactors in study areas. Small ruminant with history of retained fetal membrane (OR=3, CI: 3.52- 27) and small ruminant with abortion history (OR=32, CI: 2.26-462.8) were also found significantly associated with seropostiveity. Questioner survey revealed only $30 \%$ of the respondents were aware of the small ruminant brucellosis. Most of them (84\%) handle aborted materials with bare hand, $94 \%$ of the respondents mix sheep and goat at grazing field and watering point. Traditionally the habit of raw milk consumption is com-
\end{abstract}


mon (100\%). In conclusion, the result of this study demonstrated the presence of Brucella sero-reactors at moderate level in small ruminants and identified certain predictors of the infection. Therefore, based on the findings, authors suggest the need for further investigation on the disease-causing agent to take proactive control intervention measures. Meanwhile, actors need to work on raising public awareness to prevent the risk of public health hazard due to Brucella infection.

Key words:- Brucellosis; CFT; RBPT; Small ruminant; Zoonosis

\section{Introduction}

Brucellosis is known by different names in different host species including Melitococcosis, undulant fever, Malta fever, Mediterranean fever (in man); contagious abortion, infectious abortion, epizootic abortion (in animals); Bang's disease specifically in bovine (WHO, 2001). The disease is a highly infectious zoonotic. Wide species of domestic and wild animals suffer from the diseases worldwide, particularly in developing countries. Brucellosis is caused by facultative, intracellular and Gram- negative bacteria called Brucella (Pal et al., 2013, Adem and Duguma, 2020). Based on the differences in host preference and biochemical properties, Brucella genus classified into six (6) recognized/ classical species (Osterman and Moriyon, 2006), that is B. abortus (cattle), $B$. melitensis (sheep and goats), B. suis (pigs), B. ovis (sheep), B. canis (dogs) and $B$. neotomae (wood desert rats). Recent isolates from human (B. inopinata), from aquatic mammals (B. pinnipedialis and B. ceti), and from common vole (B. microti) are recognized as new species (Paul et al., 2015). To date, 12 different Brucella species have been described including two most recently described species, B. papinios isolated from retained placenta of baboons (Whatmore et $a l ., 2014$ ), and B. vulpis isolated from the mandibular lymph nodes of red foxes in Australia (Scholz et al., 2016).

Cross transmission of brucellosis can occur between cattle, sheep, goats, camels, equines and other domestic and wildlife (Dawood, 2008). Small ruminant brucellosis is caused by B.ovis (for sheep) and B. melitensis (mainly for goats), the latter one is the most virulent species of the Brucella genus (Pal, 2007). The disease in naturally infected sheep and goats is characterized by abortion in the last trimester of pregnancy, stillbirth and birth of weak offspring in females, and acute orchitis and epididymitis in males (Corbel, 2006). Transmission of Brucellosis in human occurs through breaks in the skin, following direct 
contact with infected tissues, blood, urine, vaginal discharges, aborted materials (fetuses or placentas), and food-borne infection occurs following ingestion of raw milk and other milk products from infected animals, but rarely from eating raw or undercooked meat of infected animals and accidental inoculation of live vaccine and occupational exposure of infection also occur in human (Gameel et al., 1993).

Complex nature of brucellosis makes it harder to treat effectively, but, longterm treatment with a combination of an antibiotic is thought to be beneficial. However, the state of the disease still does not lose its importance (Moon, 2014). To control the disease in human, prevention of the disease in reservoir host is important, so test and slaughter followed by proper disposal of seropositive animals to decrease the incidence of infection and effective vaccination and hygienic practices would reduce the disease spreading in/from endemic regions (Li et al., 2017). The obvious way to do this elimination of the disease from animals is often beyond the financial and human resources of many developing countries. In many situations there is little alternative but to attempt to minimize impact of the disease and to reduce the risk of infection by personal hygiene, adoption of safe working practices, protection of the environment and food hygiene (WHO, 2001).

Brucellosis is often persisting in the poorest and most vulnerable populations (FAO, 2003). In Africa and Central Asia where the disease is still endemic, the incidence of brucellosis is generally considered higher in livestock raised in pastoral production systems (McDermott and Arimi, 2002). In these settings, where the disease is still endemic, the prevalence of human and animal brucellosis may remain increasing, and factors such as low awareness, poor understanding of brucellosis and absence of control policies along with limited resources could be the main reasons (Ismail et al., 2019). Even though, there was no published data on small ruminant brucellosis in the study area, existing of risk factors to Brucella infection are not uncommon in pastoral and agro- pastoral areas of Ethiopia (Anteneh, 2014), and the previous studies in different geographical areas of Ethiopia shows the sero-positivity of small ruminants brucellosis (Abegaz and Yimar, 2018; Haile et al., 2018; Lakew et al., 2019; Yeshibelay and Teferi, 2019). Like other developing countries, in pastoral and agro-pastoral areas of Ethiopia, there is a limited information on prevalence of the disease and knowledge, Attitude, practices (KAP) of the communities about brucellosis (Tilahun et al., 2013; Legesse et al., 2018). 
The importance of doing such research on Small Ruminant Brucella Sero-prevalence and potential risk factor at Dallo-Manna and Haranna-Bulluk districts of Bale Zone, has two major benefits. Frist, as it has been discussed in the problem statement part, no research has been done so far to estimate seroprevalence of small ruminant brucellosis in the areas and hence the finding of this study serves as a good basis for forthcoming researchers who have a strong desire to carry out a research on this or related topics in Bale Zone, or elsewhere. Second, this study will also assess the knowledge, attitudes and practices associated with small ruminant brucellosis in Dallo-Manna and Haranna-Bulluk agro-pastoral districts of Bale zone in order to determine the risk factors that contribute to spread of the disease and to gain evidence-based information geared towards prevention and control of brucellosis both in animals and humans in the future. Therefore, the objectives of the study were to estimate the status of small ruminant brucellosis and risk factors contributed to the disease in livestock and human in study areas

\section{Materials and methods}

\section{Description of study Area}

The study area falls within two districts of the Bale zone, namely Dallo-Manna and Haranna-Bulluk. The districts have been formed in 2005 through the division of Manna-Angetu district and located at about $540 \mathrm{~km}$ southeast from the capital city, Addis Ababa. The study districts are lies between $39^{\circ} 15^{\prime} 0$ "$40^{\circ} 15^{\prime} 0^{\prime \prime} \mathrm{E}$ Longitude and 6 $17^{\prime} 30^{\prime \prime}-6^{\circ} 45^{\prime} 0^{\prime \prime} \mathrm{N}$ Latitude (Flintan et al., 2017). The annual rainfall pattern in the area is the bi-modal type, i.e., March through April (short rain season) and August through October (long rain season). Mean annual rainfall in the area actually varies from around 700 to over $1200 \mathrm{~mm}$ and the mean annual temperature is $18^{\circ} \mathrm{C}$ (Tadesse and Feyera, 2008). Even though, the exact figure is difficult to know, unpublished data from Bale zone pastoral development office in 2019 shows that the livestock populations of both districts are composed of cattle 499,403, goats 235,661 , sheep 69,901 , donkeys 27,524 , camels 43,573 , horse 8,716 and mule 4,438 .

\section{Study designs and study animals.}

A cross-sectional multistage sampling technique was involved to estimate the sero-prevalence and associated risk factors of small ruminant brucellosis. The study was carried out on local breeds of sheep and goats kept under extensive 
type of management system in the study areas were considered as a study population. Sheep and goats which were above 6 months of age and apparently healthy were included in the study. In this report, the term flock refers to a number of domestic animals, especially sheep, goats, or geese that are kept together.

\section{Sampling procedure and sample size determination}

Two districts namely Dallo-Manna and Haranna-Bulluk were selected purposively based on accessibility, the number of small ruminant population and willingness of the community in the districts. Both districts have 14 peasant associations (kebeles) each. Selection of 4 out of 14 kebeles from each district and 24 villages from a total of 84 villages in both districts was based on random sampling. Sampling of individual animals were applied randomly on the flocks of small ruminants found in selected villages, after relevant individual animal level information were recorded.

The study sample size was determined according to (Thrusfield, 2018) formula for a large population with $95 \%$ confidence level, $5 \%$ desired absolute precision by considering an expected prevalence of $8.1 \%$ (Wubishet et al., 2018) in Yabello districts of Borena Zone and 6.2\% (Wubishet et al., 2017) in Liban District of Guji Zone. Therefore, taking an average prevalence of two areas as an expected prevalence, calculated sample size was 107 . However, to increase precision, the sample size was increased by 3.59 -fold. Accordingly, 384 small ruminants were sampled based on proportional allocations of the sample size for each Kebele.

For questionnaire survey sample size was calculated using the formula given by (Arsham, 2005); $\mathrm{N}=0.25 / \mathrm{SE} 2$, where: $\mathrm{N}=$ sample size, $\mathrm{SE}$ (standard error) $=5 \%$. Thus, the required sample size for the questionnaire survey was 100 . However, only 50 volunteers were included.

\section{Sample collection}

\section{Questionnaire survey}

Semi-structured questionnaire was administered to 50 flock owners, one (1) owner per flock of Small ruminants by the local language during taking blood sampling from the animals. 
The questionnaire was designed for a survey of the potential risk factors associated with zoonotic brucellosis in sheep and goat flocks. Thus, the relevant information such as overall small ruminant flocks management practices, occurrence of abortion and presence of retained fetal membrane, knowledge about zoonotic diseases, habit of consuming raw milk and meat, handlings of aborted fetuses and contaminated materials.

\section{Serological survey}

Approximately about $5 \mathrm{ml}$ of whole blood sample was collected from the jugular vein of each small ruminants included in the study using plain vacutainer tubes and needles. Each sample tube was labeled using codes specific to the individual sample. Collected samples were kept in a slanting position overnight at room temperature to separate the serum and the clotted red blood cells (OIE, 2009). Then sera were gently transferred into sterile screw cupped Nunc tubes, labeled and transported in cold chain to Addis Ababa University, College of Veterinary Medicine and Agriculture, Bishoftu and stored at $-20^{\circ} \mathrm{C}$ until screened and tested for antibodies against natural Brucella exposure analysis using Rose Bengal Plate Test (RBPT) (Radostits et al., 2007). RBPT was done at Addis Ababa University, College of Veterinary Medicine and Agriculture, by using, B.abortus antigen and all serum samples collected were screened, according to the procedures described by (Alton, 1990; OIE, 2009). The presence of agglutination was considered positive reaction while the absence of agglutination was considered negative. Positive sera with RBPT were further tested with Compliment Fixation Test (CFT) for confirmation using standard B.abortus antigen at National Veterinary Institute (NVI). The preparation of reagents and CFT procedures were performed according to the protocols of the Federal Institute for Consumer Protection and Veterinary Medicine Service Laboratory, Berlin, Germany (OIE, 2009). Sera with strong reaction, more than $75 \%$ fixation of complement (3+) at a dilution of $1: 5$ or at least with $50 \%$ fixation of complement (2+) at a dilution of 1:10 and above or absence of sedimentation of Red blood cells were considered as positive and lack of fixation/ complete hemolysis or the presence of sedimentation of Red blood cells were considered as negative. 


\section{Data Analysis}

The data obtained from both serological tests and questioner surveys were entered into a computer on a Microsoft Excel spreadsheet. Descriptive and analytic statistics were computed using software SPSS ${ }^{\circledR}$ Version 20.0. The Chi-square $\left(x^{2}\right)$ and logistic regression tests were employed to identify possible association between risk factors and reproductive characteristics with seropositive to Brucella infection. The degree of association was considered significant when a p-value of less than 0.05 is obtained or when the $95 \%$ confidence intervals (95\% CI) in the logistic regression analysis doesn't include one or if odds ratio (OR) is different from one (Thrusfield, 2018).

\section{Results}

\section{Association of risk factors with Brucellosis at individual animal level}

For an individual sero-prevalence, among 384 small ruminant, 25 (6.5\%) tested positive by RBPT. From these, 11 (2.9\%) animals were confirmed positive by CFT. Associations of the putative risk factors were computed by Pearson's Chi-square test and the sero-prevalence of small ruminant brucellosis in abortion history, history of retained fetal membrane, parity and age were all statistically significant $(p<0.05)$.

All significant variables in Pearson's Chi-square test were also showed statistically significant $(p<0.05)$ with sero-prevalence of small ruminant brucellosis in the univariable logistic regression analysis (Table 1). 
Table 1. Effects of risk factors on the overall sero-prevalence of small ruminants' brucellosis using CFT.

\begin{tabular}{|c|c|c|c|c|}
\hline \multirow{2}{*}{$\begin{array}{l}\text { Risk factors } \\
\text { Variable }\end{array}$} & \multirow[b]{2}{*}{ Category } & \multicolumn{3}{|c|}{ Complement fixation test } \\
\hline & & OR & $\mathbf{9 5} \% \mathrm{CI}$ & p-value \\
\hline \multirow[t]{3}{*}{ Parity } & No-parity * & 2 & $1.43-8.14$ & 0.038 \\
\hline & Primiparous & & & \\
\hline & Pluriparous & & & \\
\hline \multirow[t]{2}{*}{ Flock size } & $<15$ & 1 & $0.47-5.67$ & 0.436 \\
\hline & $>15$ & & & \\
\hline \multirow[t]{2}{*}{ District } & Haranna-Bulluk & 1 & $0.56-6.80$ & 0.643 \\
\hline & Dallo-Manna & & & \\
\hline \multirow[t]{2}{*}{ Species } & Sheep & 1 & $0.29-2.32$ & 0.522 \\
\hline & Goats & & & \\
\hline \multirow[t]{2}{*}{ Sex } & Male & 1 & $0.34-4.12$ & 0.369 \\
\hline & Female & & & \\
\hline \multirow[t]{2}{*}{ Age } & Young* & 9 & $1.12-69.74$ & 0.013 \\
\hline & Mature & & & \\
\hline \multirow[t]{2}{*}{ History of Abortion } & Absent* & 71 & $8.23-603.9$ & 0.000 \\
\hline & Present & & & \\
\hline \multirow[t]{2}{*}{ History of RFM } & Absent* & 32 & 6.04-169.9 & 0.000 \\
\hline & Present & & & \\
\hline
\end{tabular}

The result of multivariate logistic regression model indicated that animals with history of retained fetal membrane (OR=3, CI: 3.52-27) and animals with history of abortion (OR=32, CI: 2.26-462.8) were also found evident in multivariable logistic regression analysis (Table 2).

Table 2. Multivariable logistic regression analysis of risk factors and small ruminant brucellosis

\begin{tabular}{lccc}
\hline Variables & \multicolumn{3}{c}{ Complement Fixation test } \\
& OR & $\mathbf{9 5 \%}$ CI & p-value \\
\hline History of abortion & 32 & $2.26-462.8$ & 0.000 \\
Retained fetal membrane & 3 & $3.52-27$ & 0.014 \\
\hline
\end{tabular}




\section{Sero-positivity of Small-ruminant brucellosis at flock level}

Out of 50 flocks included in the study half of them (50\%) were positive using RBPT and 11 flocks (22\%) was positive using CFT. Using RBPT, prevalence in Dallo-Manna is 3.8 fold (95\% OR CI=1.17-12.19) than Haranna-Bulluk showing not statistically significant association with p-value $>0.05$ (Table 3), the difference may be due to, many large flock size population of small ruminant $(\geq 15)$ were sampled from Dallo-Manna (17 large flocks), while only 9 large flocks were from Haranna-Bulluk. But it was similar at Dallo-Manna (25\%) and Haranna-Bulluk (19\%) using CFT.

Table 3. Flock level Sero-prevalence of small ruminant brucellosis

\begin{tabular}{lccccccc}
\hline Study districts & $\begin{array}{l}\text { No of } \\
\text { Examined } \\
\end{array}$ & \multicolumn{2}{l}{ RBPT } & \multicolumn{5}{c}{ CFT } \\
\cline { 3 - 8 } & Flocks & № (\%) & OR & $\mathbf{9 5 \% ~ C I ~}$ & №. (\%) & OR & 95\% CI \\
\hline Dallo-Manna & 24 & $16(67)$ & 3.8 & $1.17-12.19$ & $6(25)$ & 1 & $0.37-5.37$ \\
Haranna-Bulluk & 26 & $9(35)$ & 1 & $0.32-3.31$ & $5(19)$ & 1 & $0.25-3.97$ \\
Total & 50 & $25(50)$ & & & $11(22)$ & & \\
\hline
\end{tabular}

\section{Knowledge of brucellosis}

A total of 50 respondents, (66\% male and $34 \%$ female), were interviewed to assess their knowledge, attitude and practices towards brucellosis in both districts (24 from Dallo-Manna and 26 from Haranna-Bulluk). Little difference was observed on awareness of Brucellosis between study districts. The awareness on the zoonotic importance of the small ruminant Brucellosis in the study districts were increasing with age of the respondents. Out of all respondents $30 \%$ were aware on the zoonotic importance of Brucellosis (Table 4). 
Adem et al.,

Table 4. Participants awareness on zoonotic Brucellosis in study area $(n=50)$

\begin{tabular}{llcc}
\hline \multicolumn{2}{l}{ Parameters of Study } & $\begin{array}{l}\text { № of } \\
\text { Respondents }\end{array}$ & $\begin{array}{l}\text { № (\%) of respondents } \\
\text { with awareness }\end{array}$ \\
\hline Districts & Dallo-Manna & 24 & $6(25)$ \\
\multirow{2}{*}{ Sex } & Haranna-Bulluk & 26 & $9(35)$ \\
& Male & 33 & $11(33)$ \\
\multirow{2}{*}{ Age } & Female & 17 & $4(24)$ \\
& Young & 14 & $6(43)$ \\
& Adult & 30 & $8(27)$ \\
Total & Old & 6 & $1(17)$ \\
& & 50 & $15(30)$ \\
\hline
\end{tabular}

Most of the respondents (84\%) handle aborted materials with bare hand without protecting themselves. Mixing of shoats (sheep and goat) at day time was practiced by 47 (94\%) owners. Most of the flocks 43 (86\%) recognized the chance of contact with other flocks at grazing and watering. The habit of drinking raw milk was present all (100\%) of the respondents but almost all 48 (96\%) with no habit of consuming raw meat. Children are the most responsible personnel for rearing of the flocks $48(96 \%)$, while house wife share the remaining responsibility in rearing/herding. The majorities of milking (78\%) were practiced by women while $22 \%$ by children (Table 5 ). 
Table 5. Small ruminant management practices and utilization of products associated to transmission of Brucella to human and animals

\begin{tabular}{|c|c|c|}
\hline Study parameters & Categories & $\begin{array}{l}\text { Probability of } \\
\text { contracting the disease } \\
\text { № }(\%)\end{array}$ \\
\hline \multirow[t]{2}{*}{ Removal of aborted materials } & Bare hand & $42(84)$ \\
\hline & Protected hand & $8(16)$ \\
\hline \multirow[t]{3}{*}{ Management way of aborted materials } & Feed Dogs & $14(28)$ \\
\hline & On field and tree & $35(70)$ \\
\hline & Burying & $1(2)$ \\
\hline \multirow[t]{2}{*}{ Raw milk consumption } & Yes & $50(100)$ \\
\hline & No & $0(0)$ \\
\hline \multirow[t]{2}{*}{ Raw meat consumption } & Yes & $2(4)$ \\
\hline & No & $48(96)$ \\
\hline \multirow[t]{2}{*}{ Keeping of sheep and goat at day time } & Mixed & $37(74)$ \\
\hline & Separated & $13(26)$ \\
\hline \multirow{2}{*}{$\begin{array}{l}\text { Keeping of sheep and goat at night } \\
\text { time }\end{array}$} & Mixed & $3(6)$ \\
\hline & Separated & $47(94)$ \\
\hline \multirow{2}{*}{$\begin{array}{l}\text { Contact with other flock at watering } \\
\text { and grazing }\end{array}$} & Present & $43(86)$ \\
\hline & Absent & $7(14)$ \\
\hline \multirow[t]{3}{*}{ Responsible person for rearing/herding } & Children & $48(96)$ \\
\hline & Husband & $0(0)$ \\
\hline & Wife & $2(4)$ \\
\hline \multirow[t]{3}{*}{ Responsible person for milking } & Wife & $39(78)$ \\
\hline & Children & $11(22)$ \\
\hline & Husband & $0(0)$ \\
\hline \multirow{2}{*}{$\begin{array}{l}\text { Occurrence of abortion in female } \\
\text { animals }\end{array}$} & Present & $27(54)$ \\
\hline & Absent & $23(46)$ \\
\hline \multirow{2}{*}{$\begin{array}{l}\text { Human clinical signs (headache, fever, } \\
\text { back pain and night sweeting) }\end{array}$} & Present & $36(72)$ \\
\hline & Absent & $14(28)$ \\
\hline \multirow[t]{2}{*}{ Sick person visits clinic or hospital } & Yes & $18(36)$ \\
\hline & No & $32(64)$ \\
\hline
\end{tabular}

\section{Discussion}

In the present study the overall sero-prevalence of small ruminant brucellosis using CFT was 2.9\%. The difference in prevalence between the districts was not 
statistically significant. It could be due to the similarity in the agro-ecological conditions and livestock management system in the area. This finding is fairly in agreement with some recent studies conducted in selected pastoral and agro- pastoral low lands of Ethiopia (Sintayehu et al., 2015), Tselemti districts of Tigray region (Kelkay et al, 2017), southern zone of Tigray region (Teklue et al., 2013). Selected Settlements of Dire Dawa Administrative Council Area, Eastern Ethiopia (Haile et al., 2018), in Werer Agricultural Research Center, Afar Region, North East Ethiopia (Bezabih and Bulto, 2015) with prevalence of $1.9 \%, 1.8 \%, 3.5 \%, 2.6 \%$ and $2.3 \%$ respectively. This could be attributed to the similarity in agro-ecological conditions and livestock management system in the areas (Teshale et al., 2006). However, the result of this study is lower than the observations recorded in Tallalak district of Afar region, Ethiopia (Tadeg et al., 2015), in Chifra and Ewa districts of Afar Region (Tegegn et al., 2016), in Yabello districts of Borena Zone Oromia Regional State, Southern Ethiopia (Wubishet et al., 2018), in selected Kebeles of Amibara district of afar region (Muluken, 2016) with sero- prevalence of $13.7 \%, 12.4 \%, 8.1 \%$ and $7.5 \%$ respectively. This difference might be due to the diagnostic test used, the differences in breeding, animal management, production systems and husbandry practices (Teshale, 2006). In contrast, the observation of current study is higher than sero-prevalence rates of $0.8 \%$ reported in Babile Woreda, Eastern Hararghe, Ethiopia (Yeshibelay and Teferi 2019), 0.4\% in and around Bahir Dar, North West Ethiopia (Ferede et al., 2011), 0.7\% in and around Kombolcha, Amhara Regional State, North-Eastern Ethiopia (Tewodros and Dawit, 2015) and this variation in sero-prevalence could be due to difference in management system, the difference in sample size used and agro-ecology.

Brucellosis is considered as disease of flock importance, in this study flock level Sero-positivity of $22 \%$ was found lower when we compared to (Adugna et al., 2013) (50.5\%) and (Anteneh, 2014) (57.8\%) in Afar. This could be due to the small number of sample size in the present study in each study districts. The flock level prevalence is higher than individual animal level and this characterizes the nature and importance of the disease in the large flock size. This concept coincides with the current study that the sero-prevalence of brucellosis between the categorized flock sizes $(<15$ and $\geq 15)$ showed higher seroprevalence recorded in the large flock sizes $(3.5 \%)$ than that of small flock sizes $(2.2 \%)$ of small ruminants. This result was in agreement with the previous reports in Afar region (Adugna et al., 2013). 
The higher sero-prevalence in goats (3.4\%) than in sheep (2.3\%) in this study was in consistent with that of (Adugna et al., 2013; Bezabih and Bulto, 2015; Lakew et al., 2019). The difference in sero-prevalence between species may be in part due to the greater susceptibility of goats to Brucella infection than sheep and partly it may be due to the fact that sheep unlike goats do not excrete the Brucella organisms for longer periods of time. This can reduce the potential of the spread of the disease among sheep flock (Radostitis et al., 2007).

The study revealed that there was statistically significant difference $(p<0.05)$ in sero-prevalence of brucellosis between the young and mature age groups, higher sero-prevalence was found in mature animals (4.8\%) than young animals $(0.6 \%)$. This finding was in line with the study conducted in Werer Agricultural Research Center of Afar Region, with sero-prevalence of $2.7 \%$ in mature and $0 \%$ in young animals (Bezabih and Bulto, 2015). Sexually matured animals are more prone to Brucella infection than sexually immatured animals of either sex (Radostits et al., 2007). This might be due to the fact that as sex hormones and erythritol tend to increase in concentration with age and sexual maturity and favor growth and multiplication of Brucella organisms (Radostits et al., 2007). On the other hand, it is also true that younger animals tend to be more resistant to infection and frequently clear an established infection (Gyles and Prescott, 2004) although latent infections can occur (Walker, 1999).

There was statistically significant association $(\mathrm{p}<0.05)$ among parities and the sero-prevalence of the disease. The sero-positivity of female sheep and goats with the history of no parity, Primiparous and Pluriparous were $0(0 \%), 1(1 \%)$ and 7(6\%) respectively. This is therefore, in consistent with the previous study (Yohannes et al., 2013; Anteneh, 2014), this might be due to repeated exposure of the female animals to parturition and other physiological stress increases the probability of acquiring Brucella infection.

The analysis result also revealed that the prevalence of brucellosis between sexes did not show significant association $(p>0.05)$. The prevalence was higher in females (3.5\%) compared to prevalence in male (1.9\%). The present finding was in agreement with the records obtained from (Mengistu, 2007) who was report brucellosis in females (3.2\%) and males (1.2\%) in Adamitulu-Jido Kombolcha District, Oromia Regional State, Ethiopia. Higher susceptibility of female animals could be due to the fact that they have more physiological stresses than the males (Walker, 1999). In addition, male animals are less susceptible to Brucella infection due to the absence of erythritol (Hirsh and Zee, 1999). It 
may be due to supply of male to markets immediately upon maturation than female or shorter exposure period, while female serve as a source of milk (longer exposure period). The results obtained in this study revealed that, abortion and retained fetal membrane appears to be major risk factors for brucellosis compared with other risk factors $(p=0.000)$. This result supports the truth that reproductive problems like abortion and retained fetal membrane in small ruminant can be caused by brucellosis (Walker, 1999).

Brucellosis is transmissible from animals to humans through contaminated milk, raw milk products, and direct contact with infected animals. In the current questionnaire survey, most of the respondents (54\%) recognize the occurrence of abortion in their small ruminant flocks, but only $30 \%$ of them aware of the brucellosis and most of the respondents (84\%) were used to handle retained fetal membranes and assist delivery with unprotected hand, which have risk of transmission while contact (Radostits et al., 2007). All (100\%) of the participants in the interview consume raw milk which is one of the sources of human Brucellosis (OIE, 2009; Radostits et al., 2007), in contrast almost all (96\%) of the respondents practiced consumption of cooked meat, which reduces the risk of getting infected with Brucella. Although, 94\% of the respondents in the studied community keeps their animal separately at night time, $74 \%$ of them mix their sheep and goats at day time and $86 \%$ of them use communal grazing land with neighbor flocks. This may facilitate the transmission of the disease from infected flocks to disease free flocks, through contact during grazing and watering. Intermixing of different species and flocks of livestock occur creating a potential risk factor for interspecies and inter flock's disease transmission. Overall, mixing of different flocks and different species of animals in the study districts; lack of community awareness about brucellosis; and the habit of raw milk consumption might greatly contribute for further spread of brucellosis (Muluken et al., 2017; Lakew et al., 2019).

\section{Conclusions}

The sero-prevalence described in this study shows that brucellosis is a widespread and well-established infection between small ruminants and there were risk factors to the occurrence of the disease in livestock and human across the study districts of Bale zone. However, as the diagnostic tests used were serological there is a need for further investigation to look for circulating Brucella biotype so as to identify the target species for control intervention. Meanwhile, 
brucellosis being a disease of economic and public health significant, there is a need for intervention through creation of public awareness.

\section{Acknowledgements}

This Study was financially supported by thematic research project entitled "Epidemiological and bacteriological studies of Major livestock disease of economic and zoonotic significance in Ethiopia" funded by Addis Ababa University. We would like to acknowledge Mr. Muluken Tekle for his Laboratory assistance at college of Veterinary medicine and agriculture of Addis Ababa University, Bishoftu. Dr. Sufian Abdo, W/ro Rukia Hussein Kubo and Mr. Gazzali Muhammad and Animal owners are highly acknowledged for their assisting during sample collection in Dallo-Manna and Haranna- Bulluk districts.

\section{References}

Abegaz, S., and Yimer, Y., 2018. Comparative Sero-epidemiological Study of Brucellosis in Sheep under Smallholder Farming and Governmental Breeding Ranches of Central and North East Ethiopia. J. Vet. Med., 1: 12

Adem, A., and Duguma, A., 2020. Characteristics and Intracellular Life of Brucella Organism: A Review. J. Microb. Biochem. Technol., 12:431.

Adugna, W., Sisay, T., and Keskes, S., 2013. Sero-prevalence of small ruminant brucellosis in four districts of Afar National Regional State, Northeast Ethiopia. J. Vet. Med. Anim. Hlth., 12:358-364.

Alton, G., 1990. B. melitensis. In Animal brucellosis (K. Nielsen and R. Duncan, eds). CRC Press, Boca Raton, Florida, Pp. 383-409.

Anteneh, H., 2014. Seroprevalence of Small Ruminant Brucellosis and its Public Health Awareness in selected two Districts of Afar Region, Ethiopia. MSc Thesis, Addis Ababa University College of Veterinary Medicine and Agriculture, Bishoftu, Ethiopia.

Arsham, H., 2005. Questionnaire design and surveys sampling, $9^{\text {th }}$ edition, http://home. ubalt.edu/ntsbarsh/stat-data/Surveys.htm.

Bezabih, M., and Bulto, W., 2015. Sero-prevalence of small ruminant brucellosis in Werer Agricultural Research Center, Afar Region, North East Ethiopia. J. Microbiol. Res., 3(2): 031-035

Corbel, M., 2006. Brucellosis in humans and animals. Produced by the, WHO in collaboration with the, FAO and OIE, Geneva. 
Dawood, A., 2008. Brucellosis in Camels (Camelus dromedorius) in the south province of Jordan. Am. J. Agri. Biol. Sci., 3: 623-626.

Ferede, Y., Mengesha, D., Mekonen, G. and Hilemelekot, M., 2011. Study on the seroprevalence of small ruminant brucellosis in and around Bahir Dar, North West Ethiopia. Ethiop. Vet. J., 15 (2), 35-44

Flintan, F., Chibssa, W., Tadesse, T., Muhammed, M., and Kassim, S., 2017. LivestockBased Land Use and Change in the Bale Mountains Eco-Region: A Comparative Study between 2007 and 2016, ILRI (International Livestock Research Institute), Pp. 45-84, Addis Ababa, Ethiopia.

FAO, 2003. FAO Guidelines for coordinated human and animal brucellosis surveillance. Food and Agricultural Organization (FAO), Animal Production and Health Paper 156, Rome, Italy. Pp. 1-45.

Gameel, S., Mohamed, S., Mustafa, A. and Azwai, S., 1993. Prevalence of camel brucellosis in Libya. Trop. Anim. Hlth. Prod., 25: 91-93.

Gyles, C., and Prescott, F., 2004. Themes in bacterial pathogenic mechanisms. In: Gyles, C.L., Prescott, F.J., Songer, G.J., Thoen, O., ed. Pathogenesis of bacterial infections in animals. 3rd ed. Australia: Blackwell Publishing. Pp. 309-315.

Haile, G., Teshome, A., and Nigussie, L., 2018. A Sero-Prevalence of Small Ruminant Brucellosis in Selected Settlements of Dire Dawa Administrative Council Area, Eastern Ethiopia, ARC. J. Immunol. Vaccines., 3 (2):7-14.

Hirsh, D and Zee, Y., 1999. Veterinary microbiology. Cambridge, Massachusetts: Blackwell Science Inc., UK.

Ismail, A., Angara, T. and Ibrahim, A., 2019. Knowledge, Attitudes and Practices Associated with Brucellosis in Small-holder Dairy Farms in Suburbs of Khartoum State, Sudan, Department of Preventive Medicine, College of Veterinary Medicine, University of Bahri, Khartoum Sudan. EC. Vet. Sci., 4(4), 241-250.

Kelkay, M., Gugsa, G., Hagos, Y. and Taddelle, H., 2017. Sero-prevalence and associated risk factors for Brucella sero-positivity among small ruminants in Tselemti districts, Northern Ethiopia. J.Vet. Med. Anim. Hlth., 9 (11), 320-326.

Lakew, A., Hiko, A., Abraha, A. and Mengistu, S., 2019. Sero-prevalence and community awareness on the risks associated with Livestock and Human brucellosis in districts of Fafan zone, of Somaliland, Ethiopia. Vet. Anim. Sci., 7:100047

Legesse, M., Medhin, G., Bayissa, M. and Mamo, G. 2018. Knowledge and perception of pastoral community members about brucellosis as a cause of abortion in animals and its zoonotic importance in Amibara district, Afar Region, Ethiopia. Plos. One., $1-12$ 
Li, T., Tong, Z., Huang, M., Tang, L., Zhang, H. and Chen, C. 2017. Brucella melitensis M590Dbp26 as a potential live vaccine that allows for the distinction between natural infection and immunization. Can. J. Microbiol., 63: 719-729

McDermott, J and Arimi, S., 2002. Brucellosis in Sub-Saharan Africa: epidemiology, control and impact. Vet. Microbiol., 20:111-134.

Mengistu, M., 2007. Sero-epidemiology of brucellosis in small ruminants in southern Ethiopia, MSc thesis, Addis Ababa University, Faculty of Veterinary Medicine, Bishoftu, Ethiopia.

Moon, M., 2014. Tuberculosis of spine: Current views in diagnosis and management. Asian Spine. J., 8:97-111

Muluken, G., Abrha, B. and Abebe, M., 2017. Assessment of Community Knowledge, Attitude and Practice on Zoonotic Disease in and Around Dodola Town, West Arsi Zone, Ethiopia. Ethiop. J. Vet. Sci. Anim. Prod., 1(1): 57-65.

Muluken, T., 2016. Seroprevalence of brucellosis and isolation of Brucella from Small ruminants that had history of recent abortion in selected Kebeles of amibara district, afar region, Ethiopia. MSc thesis. College of Veterinary medicine and Agriculture, Addis Ababa University, Bishoftu.

OIE, 2009. OIE Manual of diagnostic tests and vaccines for terrestrial animals. Office international des epizooties (OIE) Paris, France. Pp.1-9.

Osterman, B. and Moriyon, I., 2006. International Committee on Systematics of Prokaryotes; Subcommittee on the taxonomy of Brucella: Minutes of the meeting, 17 September 2003, Pamplona, Spain. Inter. J. Syste. Evolu. Microbiol., 56, 1173 1175 .

Pal, M., 2007. Zoonoses.2 ${ }^{\text {nd }}$ Edition. Satyam Publishers. Jaipur, India, Pp. 98-99.

Pal, M., Tesfaye, S. and Dave, P., 2013. Zoonosis occupationally acquired by abattoir workers. J. Env. Occupational Sci., 2:155-162.

Paul, F., Thomas, A., Allison, R., Carlos, A., Rossetti, L. and Garry, A., 2015. Pathogenesis and Immunobiology of Brucellosis-Review of Brucella Host Interactions, Am. J. Pathol., 185 (6):1505-1517.

Radostits, M., Gay, C., Hinchcliff, W. and Constable, D., 2007. Veterinary Medicine: A Textbook of the Diseases of Cattle, Sheep, Pigs, Goats and Horses, $10^{\text {th }}$ ed. Saunders Company, Philadelphia, U.S.A. Pp. 962-984.

Scholz, C., Revilla-Fernández, S., Al Dahouk, S., Hammerl, A., Zygmunt, S., Cloeckaert, A. et al., 2016. Brucella vulpis sp. nov., isolated from mandibular lymph nodes of red foxes (Vulpes vulpes). Inter. J. Syste .Evolu.Microbiol., 66, 2090-2098. 
Sintayehu, G., Melesse, B., Abayneh, A., Sintayehu, A. and Melaku, S., 2015. Epidemiological survey of brucellosis in sheep and goats in selected pastoral and agropastoral lowlands of Ethiopia. Rev. Sci.Tech. Off. Int. Epiz., 34 (3).

Tadeg, W., Gudeta, F., Mekonen, T., Asfaw, Y., Birru, A. and Reda, A., 2015. Seroprevalence of small ruminant brucellosis and its effect on reproduction at Tallalak district of Afar region, Ethiopia. J. Vet. Med. Anim. Hlth., 7(4): 111-116.

Tadesse, W and Feyera, S., 2008. Sustainable Management and Promotion of Forest Coffee in Bale, Ethiopia, Bale Eco-Region Sustainable Management Programme, SOS Sahel/FARM-Africa, August 2008, Addis Ababa.

Tegegn, A., Feleke, A., Adugna, W. and Melaku, S., 2016. Small Ruminant Brucellosis and Public Health Awareness in Two Districts of Afar Region, Ethiopia. J. Vet. Sci. Technol., 7 (335): 2.

Teklue, T., Tolosa, T., Tuli, G., Beyene, B. and Hailu, B., 2013. Sero-prevalence and risk factors study of brucellosis in small ruminants in Southern Zone of Tigray Region, Northern Ethiopia. Trop. Anim. Hlth Prod., 45: 1809-1815.

Teshale, S., Muhie, Y., Dagne, A. and Kidanemariam, A., 2006. Seroprevalence of small ruminant brucellosis in selected districts of Afar and Somali pastoral areas of Eastern Ethiopia: The impact of husbandry practice. Revue Med. Vet., 157:557-563.

Tewodros, A., and Dawit, A., 2015. Sero-Prevalence of Small Ruminant Brucellosis in and around Kombolcha, Amhara Region, North-Eastern Ethiopia. J. Vet. Sci. Med. Diagn., 4 (5).

Thrusfield, M., 2018. Veterinary Epidemiology, Fourth Edition, Veterinary Clinical Sciences Royal (Dick) School of Veterinary Studies, University of Edinburgh, Blackwell Publishing company, by John Wiley and Sons Ltd. UK. Pp. 270-294.

Tilahun, B., Bekana, M., Belihu, K. and Zewdu, E., 2013. Camel brucellosis and management practices in Jijiga and Babile districts, Eastern Ethiopia. J. Vet. Med. Anim. Hlth, 5: 81-86.

Walker, R., 1999. Brucella In: Veterinary microbiology.1st ed. Hirsh DC, Zee CY, ed. London: Blackwell Science Inc. Pp. 196-203.

Whatmore, A., Davison, A., Cloeckaert, S., Al Dahouk, M., Zygmunt, S. and Brew, L. et al., 2014. Brucella papionis sp. nov. isolated from baboons (Papio sp.). Inter. J. Syste. Evolu. Microbiol, 64, 4120-4128.

WHO, 2001, WHO Manual for Zoonosis and Communicable Diseases Common to Man and Animals, World Health Organization (WHO) Scientific and Technical Publication No. 580, Third Edition, Washington, D.C. 20037 U.S.A.2001;1:41- 67. 
Wubishet, Z., Golo, D., Chala, F., Shubisa, A., Huqa, L. and Godana, H. et al., 2017. Sero-Prevalence of Brucellosis in Goats and Community Awareness in Liban District of Guji Zone, Oromia Regional State, Southern Ethiopia. J. Pub. Hlth., 2 (3).

Wubishet, Z., Sadik, K., Abdala, B., Mekonnen, B., Getachew, T and Getachew, K. 2018. Small Ruminant Brucellosis and Awareness of Pastoralists Community about Zoonotic Importance of the Disease in Yabello districts of Borena Zone Oromia Regional State, Southern Ethiopia. J. Biomedical. Eng. Biosci., 12 (1): 555827.

Yeshibelay, G., and Teferi, A., 2019. Sero-Prevalence of Caprine Brucellosis in Babile Woreda, Eastern Hararghe, Ethiopia. J. Dairy. Vet. Sci., 10(3): ID.555789

Yohannes, M., Degefu, H., Tolosa, T., Belihu, K., Cutler, R., Cutler, S. et al., 2013. Brucellosis in Ethiopia. Afric. J. Microbiol. Res., 7: 1150-1157. 